\title{
Seasonal variability of gelatinous zooplankton during an anomalously warm year at Cabo Pulmo National Park, Mexico
}

\author{
Angel Antonio Silveyra-Bustamante ${ }^{1}$, Jaime Gómez-Gutiérrez ${ }^{1}$, Eduardo González-Rodríguez ${ }^{2}$ \\ Carlos Sánchez $^{3}$, Agustín Schiariti $^{4}$ \& María A. Mendoza-Becerril ${ }^{5}$ \\ ${ }^{1}$ Centro Interdisciplinario de Ciencias Marinas, Instituto Politécnico Nacional, La Paz \\ Baja California Sur, México \\ ${ }^{2}$ Centro de Investigación Científica y de Educación Superior de Ensenada (CICESE) \\ Unidad La Paz, La Paz, Baja California Sur, México \\ ${ }^{3}$ Departamento Académico de Ciencias Marinas y Costeras, Universidad Autónoma de Baja California Sur \\ La Paz, Baja California Sur, México \\ ${ }^{4}$ Instituto Nacional de Investigación y Desarrollo Pesquero (INIDEP), Mar del Plata, Argentina \\ ${ }^{5}$ CONACyT, Centro de Investigaciones Biológicas del Noroeste, La Paz, Baja California Sur, México \\ Corresponding author: Jaime Gómez-Gutiérrez (jagomezg@ipn.mx)
}

\begin{abstract}
The seasonal variability of gelatinous zooplankton (siphonophores, medusae, and thaliaceans) abundance was investigated at Cabo Pulmo National Park (CPNP) from weekly zooplankton samples collected throughout 2014. The Gulf of California had prolonged warming during 2009-2019, with 2014 as the anomalously warm year preceding El Niño 2015-2016 compared to the 2003-2020 SST time series. Gelatinous zooplankton accounted $<1 \%$ of the entire zooplankton community abundance at CPNP during 2014, suggesting a low influence of predation pressure upon their zooplanktonic and micronekton preys. Siphonophores (57\%), thaliaceans $(42 \%)$, and medusae $(1 \%)$ were present throughout the year. The abundance of gelatinous zooplankton had a significant negative association with sea surface temperature and a positive association with sea surface chlorophyll- $a$ concentration and velocity and direction of the wind, increasing their abundance during October after the hurricane season. The gelatinous zooplankton species assemblage at the coastal CPNP was similar but less abundant than the gelatinous zooplankton species assemblage observed in the oceanic region of the southern Gulf of California during summer 2014. Tropical species Diphyes dispar, Abylopsis tetragona, Chelophyes contorta, and Thalia spp. numerically dominated the gelatinous zooplankton community associated with a regional heatwave period recorded during 2014. A high proportion of tropical zooplankton indicates that mesotrophic conditions sustain the current high biomass and diversity of nektonic and benthonic planktophagous fauna inhabiting CPNP. However, prolonged warming events might decrease zooplankton biomass in the southern region of the Gulf of California in the future.
\end{abstract}

Keywords: gelatinous zooplankton; seasonal succession; species assemblages; tropical assemblage; warm conditions; Gulf of California

\section{INTRODUCTION}

Gelatinous zooplankton has attracted scientific and general public attention due to anomalous increases in population associated with the current climatic change in several regions of the world (Brodeur et al., 1999; Attrill et al., 2007; Boero et al., 2016). However, the current paradigm of a global increase in gelatinous zooplankton is so far unsubstantiated (Condon et al., 2012). Gelatinous zooplankton blooms may have pro- found ecological consequences modifying the pelagic trophic web due to their feeding habits (Finenko et al., 2006) and an increase of their biomass population featured with low carbon $(<16 \%)$ and high-water body content (Bailey et al., 1995). They include numerous voracious carnivore predators (medusae, siphonophores, and ctenophores) consuming up to $10 \%$ of the secondary production daily (Finenko et al., 2006), or competitors of herbivorous zooplankton (thaliaceans) (Martinussen \& Båmstedt, 1999). Additionally, several

Corresponding editor: Sergio Palma 
commercial fish species are significant direct or opportunist predators of gelatinous zooplankton, compensating their low carbon content with their high abundances that occasionally may increase the fish population (Diaz-Briz et al., 2017, 2018). However, the proliferation of gelatinous zooplankton could be a temporal biological threat for planktonic and nektonic biota (Graham et al., 2014) or even threaten the ecoturism activities (Ghermandi et al., 2015), potentially decreasing the income of people that depend on this economic activity.

Few studies of medusae and siphonophores collected during oceanographic cruises (EsquivelHerrera, 1990; Guerrero-Ruiz, 2016) and diving observations of gelatinous zooplankton (Hamner et al., 1975; Purcell, 1980; Gasca \& Haddock, 2004) have been done in the Gulf of California. The present study is the first annual time series of community structure and abundance, of gelatinous zooplankton in the Gulf of California. Cabo Pulmo National Park (CPNP) it the most successful national park in the Gulf of California and is one of the few locations that maintain the highest ecological index inside the gulf (expressed in fish biomass and the number of trophic levels) (AburtoOropeza et al., 2011, 2015). The seasonal abundance of fish eggs identified genetically showed evidence that at least 157 fish species spawn in CPNP (Ahern et al., 2018). A small scuba diving ecoturim industry benefits the local population, which depends on fish schools' high biomass.

Jellyfish can respond fast to environmental changes blooming under favorable environmental conditions like warmer temperatures or high availability of suitable prey (Purcell, 2005). Ahern et al. (2018) demonstrated a prolonged warming period with anomalous low sea surface chlorophyll- $a$ concentration (Chl- $a$ ) at CPNP during 2009-2016. An anomalous warming event, called "The Blob," was observed during 2013-2014 in the north central Pacific (Kintisch et al., 2015; Cavole et al., 2016). However, the presence of "The Blob" in the southern Gulf of California is still under debate. The 2014 warm event is currently considered a regional heatwave simultaneous, but independent from "The Blob" (Peterson et al., 2015, 2017; Beltrán-Castro et al., 2020). The regional 20132014 heatwave was followed by the Equatorial El Niño 2015-2016, causing prolonged warming conditions in the Gulf of California (Robinson et al., 2013, 2016; Robinson, 2016; Beltrán-Castro et al., 2020). The increase in temperature in the southern Gulf of California promotes changes in the zooplankton community structure numerically dominated by tropical species (Brinton et al., 1986; Badan, 2003). Purcell (2008) reported that jellyfish' blooms have become problematic, especially after 1980, likely associated with global warming that promotes north- ward shift distribution range of tropical zooplankton. Therefore, considering the prolonged warm conditions prevailing in the Gulf of California during the 20092016 periods (Robinson et al., 2016; Ahern et al., 2018; Beltrán-Castro et al., 2020) and the fast response of gelatinous zooplankton to these conditions, we hypothesize that the assemblage of gelatinous zooplankton will have high abundance and influence the rest of the zooplankton community due to the anomalously warm conditions observed at CPNP during 2014. The of the present study goal was to investigate the seasonal abundance and composition of gelatinous zooplankton taxonomic groups during the anomalous warm conditions recorded during 2014 in the tropical Cabo Pulmo National Park, Gulf of California.

\section{MATERIALS AND METHODS}

\section{Environmental data}

Daily sea surface temperature (SST), sea surface chlorophyll- $a$ concentration, and wind speed and direction of the CPNP region during 2014 were obtained from satellite telemetry (Figs. 1a-b). The four environmental variables daily values of the were calculated the weekly averages throughout the entire time series to match with the 42 weeks when zooplankton samples were collected (Fig. 1a-b).

\section{Sea surface temperature}

The monthly and daily SST was obtained from NASA Aqua satellite infrared sensor product of $1 \times 1 \mathrm{~km}^{2}$ (https://podaac.jpl.nasa.gov/Multi-scale_Ultra-high_ Resolution_MUR-SST) for 2003-2020. The SST was analyzed using the level 4 (L4) of the multi-sensor of ultra-high resolution (MUR) named Group HighResolution Sea Surface Temperature (GHRSST, https://www.ghrsst.org) (Chin et al., 2017). This SST product has global coverage with high spatial and temporal resolution. It does not have problems with cloudiness (Chin et al., 2017), making it ideal for the present study with small scale and high-frequency phenomena in the coastal area. All the daily pixels $(\mathrm{n}=$ 64) inside the $71 \mathrm{~km}^{2}$ polygon of CPNP were averaged to get one daily value of 2014 to analyze the annual seasonal pattern and the entire time series's monthly values 2003-2020 (Fig. 1b). Thus, monthly SST anomalies were calculated based on monthly average values for 2003-2020 to show evidence of the persistence of positive SST anomalies observed during the study (2014). The SST anomaly of each month was calculated as follows:

$$
\mathrm{Z}_{i j}=\mathrm{X}_{i j} \mathrm{Y}_{j}
$$




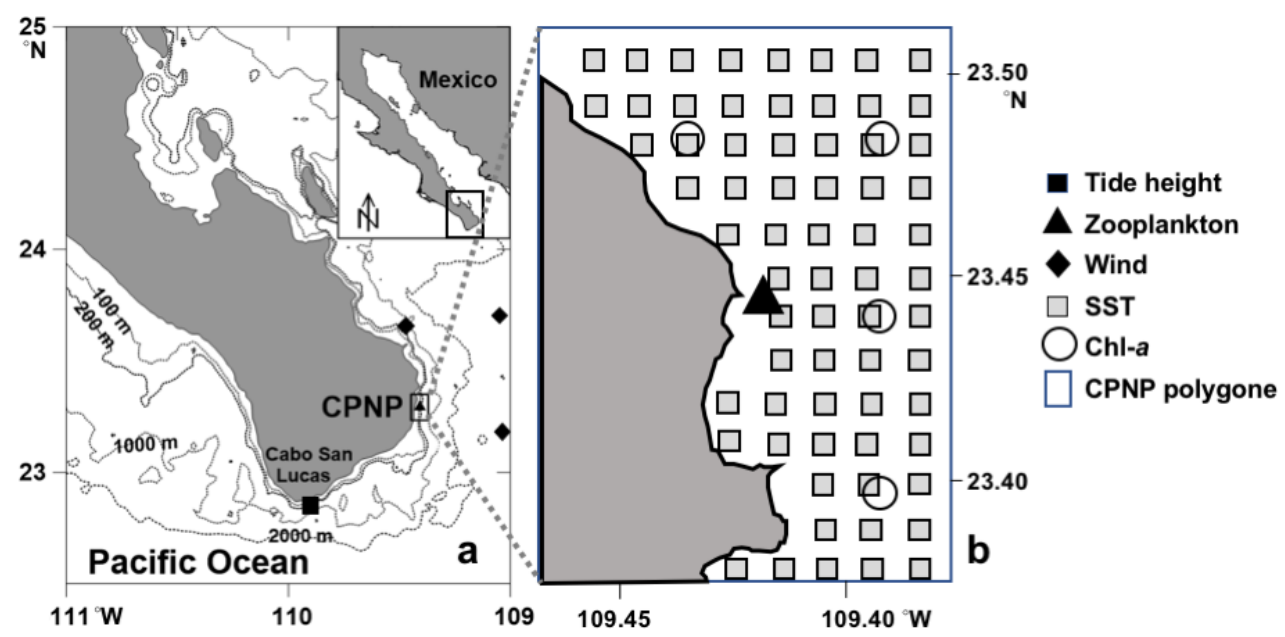

Figure 1. Area of the study showing a) Cabo Pulmo National Park (CPNP) polygone, black square shows the location of the modeled tide height time series and the black rhombus show locations where was extracted data of wind speed and direction, b) polygon of the CPNP shoeing biological and satellite information for environmental time series during 2014. Grey squares are pixels where was extracted the data of satellite SST; empty circles show locations where was obtained satellite sea surface Chl- $a$ concentration, and black triangle shows the location of zooplankton sampling station at CPNP.

where $\mathrm{Z}_{i j}$ is the anomaly of $j$ month in the $i$ year, $\mathrm{X}_{i j}$ is the variable value in the $\mathrm{j}$ month of $i$ year, and $\mathrm{Y}_{j}$ is the mean SST value in the $j$ month.

\section{Sea surface chlorophyll- $a$ concentration}

Sea surface chlorophyll- $a$ concentration $\left(\mathrm{mg} \mathrm{m}^{-3}\right)$ was obtained from daily satellite L4 products of $4 \times 4 \mathrm{~km}^{2}$ resolution, including four pixels inside the $71 \mathrm{~km}^{2}$ polygon of CPNP during 2014 (Fig. 1b). The sea surface chlorophyll- $a$ concentration was obtained from the European Space Agency Copernicus website (https://www.esa.int/Our_Activities/Observing_the_ Earth/Copernicus). This product does not have problems with cloudiness. The same procedure used in SST was performed to get the daily Chl- $a$ anomaly time series (Fig. 1b).

\section{Wind speed and direction}

Daily mean wind zonal $u$ and meridional $v$ components at $10 \mathrm{~m}$ above sea surface were obtained from NOAANCEP North American Regional Reanalysis (NARR, https://www.esrl.noaa.goy/psd/data/gridded/data.nar.ht $\mathrm{ml}$ ), with a resolution of $33 \times 33 \mathrm{~km}^{2}$ selecting three daily data pixels closest to CPNP polygon area (https://www.esrl.noaa.gov/psd/data/gridded/data.narr. monolevel.html) (Fig. 1b). The wind speed $\left(\mathrm{m} \mathrm{s}^{-1}\right)$ was estimated by calculating $u$ and $v$ daily components' hypotenuse. A daily time series of wind speed and direction was done for 2014.

\section{Tide range}

Daily tide height was obtained from Cabo San Lucas station $\left(22^{\circ} 52^{\prime} \mathrm{N}, 109^{\circ} 54^{\prime} \mathrm{W}\right.$ located $78 \mathrm{~km}$ south of Cabo Pulmo National Park) using CICESE software MAR V1.0 (https://predmar.cicese.mx/programa/) (Fig. 1a). The time lag of the predicted tidal height from Cabo San Lucas with CPNP was considered negligible. The tide amplitude allows detecting periods with spring tides (daily values above the long-term average associated with stronger tidal currents) and neap tides (daily values below the long-term average associated with weaker tidal currents).

\section{Fieldwork}

Zooplankton samples were collected at CPNP $\left(23^{\circ} 27^{\prime} \mathrm{N}, 109^{\circ} 25^{\prime} \mathrm{W}\right)$ approximately every week from the second week of January to the last week of December (2014) (Ahern et al., 2018). The zooplankton sampling station was located over the largest coral reef in the seafloor zone with approximately $30 \mathrm{~m}$ depth. Zooplankton was collected with a cylinderconical net $(60 \mathrm{~cm}$ mouth diameter $333 \mu \mathrm{m}$ mesh size) equipped with a calibrated digital flow meter (General Oceanic's, model 2030R6) to estimate the volume of filtered seawater. The zooplankton net was towed horizontally near the sea surface ( $<5 \mathrm{~m}$ of depth) in a circular track for $10 \mathrm{~min}$ at $<4 \mathrm{~km} \mathrm{~h}^{-1}$. Each zooplankton sample was preserved in non-denatured ethanol at $96 \%$ concentration. A total of 42 weekly zooplankton samples were collected throughout the year, roughly 
proportionally distributed among seasons. Seasonal low temperatures (cold period) prevail in the Gulf of California from December to May and high temperatures (warm period) from July to October, including two brief transition periods in June and November (Hidalgo-González \& Alvarez-Borrego, 2004). The cold period included 18 zooplankton samples (weeks), the warm period had 15 samples (weeks), and the transitional months had nine samples (four in June and five in November). Ten weekly samples were not collected due to logistical problems or unsuitable weather conditions.

\section{Laboratory work}

Gelatinous zooplankton was sorted out, counted, and identified from all the zooplankton samples and observed details of morphological structures with a light microscope (Olympus, model BX51). The rest of the zooplanktonic community was counted and identified into large zooplankton taxonomic groups from three $10 \mathrm{~mL}$ aliquot obtained sequentially without replacement with a Stempel pipette of $10 \mathrm{~mL}$ to account for rare zooplankton taxa.

Because several gelatinous zooplankton species form colonies and break apart during zooplankton collection with trawling nets, the siphonophores of the suborder Calycophorae were considered as an individual counting specimen with the anterior nectophore. Siphonophores of the suborder Physonectae were considered as an individual only specimen with the presence of the nectosome with pneumatophore and the syphosome because these morphological structures are present only one of per colony. The nectophores and bracts were not counted because each colony could have more than one (Pugh, 1999). The abundance of specimens of the suborder Cystonectae was estimated counting only organisms with a large float or pneumatophore and syphosome with gastrozooids or tentacles (Suárez \& Gasca, 1991). We considered a thaliacean individual each zooid regardless of whether it was aggregated or solitary (Hereu et al., 2006). We focused on abundance (rather than biomass) and trophic ecology of gelatinous zooplankton counting organisms with the ability to feed. For example, thaliaceans (indepen-dently if they formed a colony or not) always filter food, and therefore, all the specimens were counted. However, in siphonophores, only the anterior nectophore in the polygastric stage of calycophores was taken into account (Alldredge \& Madin, 1982; Suárez $\&$ Gasca, 1991). Medusae were count as an individual specimen with an umbrella complete enough to warrant adequate taxonomic identification. All these standard criteria to count individuals warranted the minimum abundance estimation of each gelatinous zooplankton taxonomic group. Gelatinous zooplankton was taxonomically identified to the lowest possible taxonomic level using taxonomic keys and specialized literature (Russell, 1953; Yount, 1954; Palma, 1973; Bouillon, 1999; Godeaux, 2003; Mapstone \& Arai, 2009; Kim et al., 2010, 2011). Each identified taxon's current taxonomic status was corroborated with the World Register of Marine Organisms database (WORMS, http://www.marinespecies.org). The abundance of all the zooplanktonic taxa (including gelatinous zooplankton) was standardized to the number of individuals per $1000 \mathrm{~m}^{3}$ (ind $1000 \mathrm{~m}^{-3}$ ) (Smith \& Richardson, 1979).

\section{Statistical methods}

Three data matrices were analyzed: a) gelatinous zooplankton species matrix (42 sampling weeks, 22 taxa), b) gelatinous zooplankton species plus the rest of the zooplankton taxonomic groups (42 sampling weeks, 46 taxa), and c) weekly averages of the environmental variables (42 sampling weeks, five environmental variables). The abundance of each taxon at each sampling station was $\log (\mathrm{x}+1)$ transformed, and each environmental variable was relativized (percentage) to give variables similar weight among environmental variables independently of their respective scale variability (Gómez-Gutiérrez et al., 2005). All multivariate statistical analyses were calculated with the software PCORD v.6 (https://www.wildblueberry media.net/software) (McCune et al., 2002).

A two-ways cluster analysis (CA) was done to infer if gelatinous zooplankton assemblages were distinct among seasons. The Flexible Beta-binding method $(-0.25)$ and Bray-Curtis distance were used to calculate the two-ways cluster analysis to determine the groups based on their similitude of sampling units for each taxon. It is the most robust clustering method currently available for their combinatorial, compatible, and space-conserving characteristics compared to other linkage and distance measure methods (McCune et al., 2002).

A non-metric multidimensional scaling (NMDS) was done to infer how seasonal gelatinous zooplankton abundance varied as a function seasonal environmental variability of gradients from five environmental variables and the standardized abundance of the rest of the zooplankton taxa community. The non-parametric ordination method is well-suited to data that are nonnormal or have discontinuous scales, such as species with disproportional dominance in their abundances within the species assemblage (McCune et al., 2002). The NMDS was done including the jellyfish zooplankton plus the rest of the zooplankton taxonomic groups using the Bray-Curtis distance measure with a 
configuration of analysis in three axes, 250 interactions, 9999 runs with real data, 249 randomized runs, and using a stability criterion of 0.0000001 (McCune et al., 2002; Gómez-Gutiérrez et al., 2005). The proportion of variance represented by each axis was calculated with the coefficient of determination $\left(\mathrm{R}^{2}\right)$ between distance in the original space's ordination and distance. The orientation of the axes derived from NMDS is arbitrary. Therefore, the plots were rotated such that the second axis corresponds to the axis of maximum environmental variability of sea surface temperature and Chl- $a$ gradients. We used different symbols using categorical variables to distinguish weekly sampling units and zooplankton taxonomic groups to better visualize environmental gradients with the same orientation of the axes.

We did the multi-response permutation procedure (MRPP) to test for significant differences in the abundance, of each gelatinous taxa or each zooplankton taxonomic group, between the cold (December-June) and warm (July-November) periods under observed seasonal climatology pattern of the Gulf of California (Hidalgo-González \& Alvarez-Borrego, 2004). The MRPP was calculated using the Bray-Curtis distance measure, weighting option $[n / \operatorname{sum}(n)]$, and then the distance environmental matrix's transformation. MRPP provides the statistic $A$. This value is a descriptor of within-group homogeneity compared to the random expectation. Thus, the observed $A=1$ when all gelatinous zooplankton species and the rest of zooplankton taxonomic groups are identical within groups of stations predefined by a hypothetical environmental condition; it is the highest possible value of $A . A=0$ when heterogeneity equals chance expectation. If $A$ has a negative value, there is less agreement within station groups than expected by chance (McCune et al., 2002).

\section{RESULTS}

\section{Seasonal environmental conditions Sea surface temperature (SST)}

The anomaly of the monthly average of satellite sea surface temperature recorded at Cabo Pulmo National Park polygon showed clear evidence that the period of study (2014) was an anomalously warm year compared with the monthly SST time series recorded during 2003-2020 (Fig. 2). The SST at CPNP showed two distinct seasons with a regional average of $26.8^{\circ} \mathrm{C}$ during 2014 (Fig. 3a). The cold season with SST between $22-26.8^{\circ} \mathrm{C}$ lasted seven months (January-May and November-December 2014), and the warm season with SST between $26.8-31.3^{\circ} \mathrm{C}$ lasted five months (June-October) (Fig. 3a).

\section{Chlorophyll- $a$ concentration}

The seasonal variability of Chl- $a$ during 2014 had a regional average concentration of $0.26 \mathrm{mg} \mathrm{m}^{-3}$ with an inverse seasonal pattern than SST. The lower sea surface Chl- $a$ concentrations were mostly observed during the end of the cold season (April-May) and the warm season (June-October, 0.06-0.26 $\mathrm{mg} \mathrm{m}^{-3}$ ) and the highest during the cold season beginning of the (November-March 0.26-0.95 $\mathrm{mg} \mathrm{m}^{-3}$ ) (Fig. 3b). Overall, CPNP had mesotrophic conditions during 2014, proper of tropical neritic habitat.

\section{Wind velocity and direction}

Northwards winds (10 m above sea surface) prevailed during the cold season (January-April) and end of the warm season (October-December) (Fig. 3c). Southwards winds predominated mostly during the end of the cold season and early warm season (April-September), and the northwards winds were considerably more intense (with a maximum speed of $9.2 \mathrm{~m} \mathrm{~s}^{-1}$ ) than southwards winds $\left(1.1 \mathrm{~m} \mathrm{~s}^{-1}\right)$. However, the hurricane Odile hit CPNP during Sep 2014 with mean sustained speeds up to $8.5 \mathrm{~m} \mathrm{~s}^{-1}$ (Fig. 3c).

\section{Tidal height}

The mean tidal height range was $1.15 \mathrm{~m}$. Tides were bigger during the first three months of the year (January-March) than during the rest of the year. During April and September, spring tides were shorter in duration and less intense than during the rest of the year (Fig. 3d). The tidal height showed spring and neap cycles with no evident clear seasonal pattern throughout the year, even during the hurricane "Odile" (September) (Fig. 3d).

\section{Zooplankton community of CPNP}

The entire zooplankton community included 24 taxa recorded during 2014 in CPNP. Eleven holoplanktonic taxa (Appendicularia, Chaetognatha, Cladocera, Copepoda, Euphausiacea, Foraminifera, Mysidacea, Ostracoda, Radiolaria, Siphonophora, and Thaliacea), seven meroplanktonic taxa (Bivalvia, Cephalopoda, Cirripedia, Cumacea, Echinodermata, Stomatopoda, and Teleostei), and other six taxa with both life-cycle strategies (Amphipoda, Annelida, Decapoda, Hydrozoa, Isopoda, and Gastropoda) were observed. The copepods $(68.74 \%)$, chaetognaths $(14.90 \%)$, and decapods $(2.63 \%)$ were the most abundant zooplanktonic taxa. Gelatinous zooplankton showed overall low abundance. Siphonophores represented $0.24 \%$, thaliaceans $0.17 \%$, and medusae $0.01 \%$ of the total abundance of zooplankton community in CPNP during 2014. 


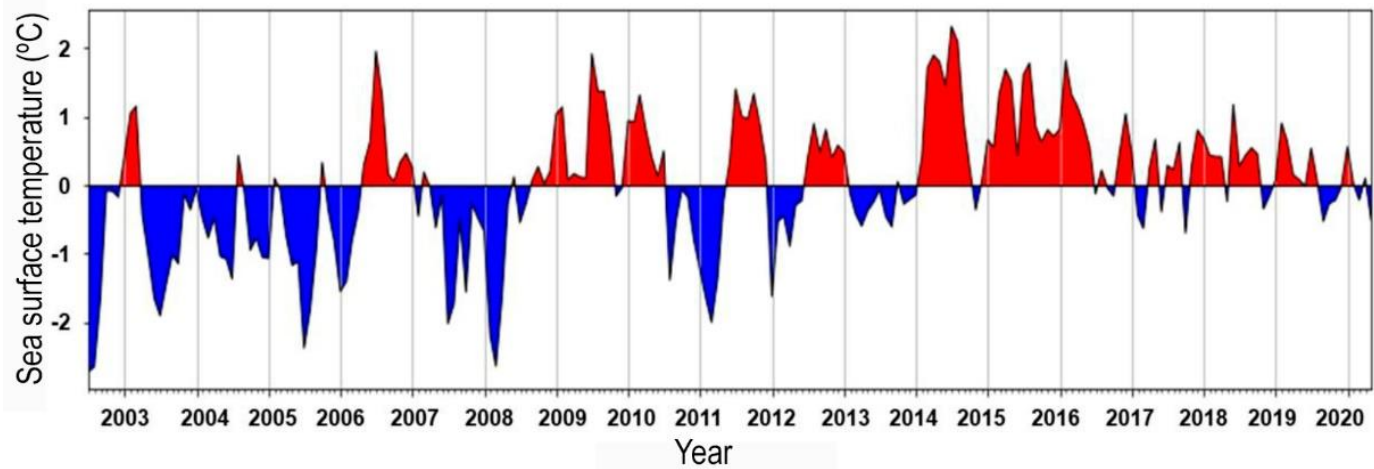

Figure 2. Anomaly of the monthly average of satellite sea surface temperature recorded at Cabo Pulmo National Park polygon recorded during 2003-2020. Evidence that demonstrated that the period of study was an anomalous warm year (2014).

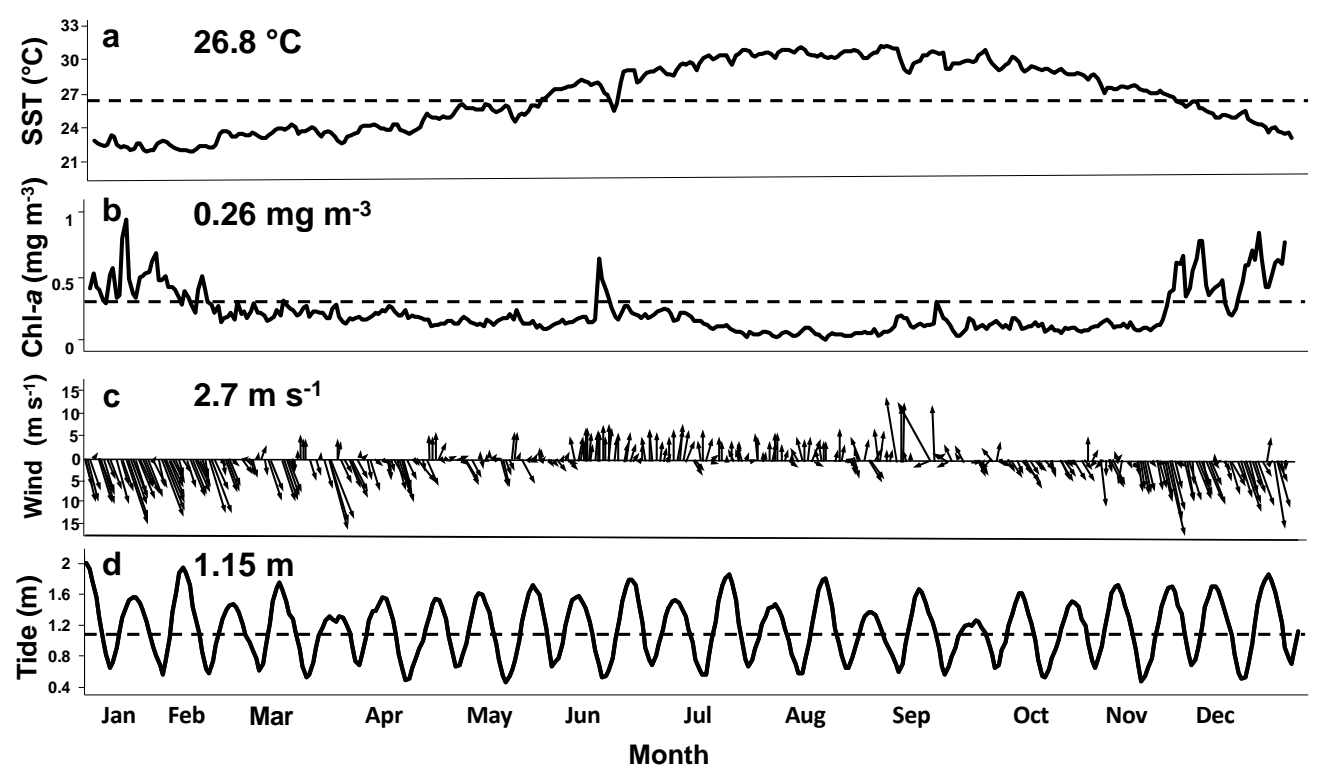

Figure 3. Daily variability of environmental conditions recorded during 2014 at Cabo Pulmo National Park polygon. a) Sea surface temperature $\left.\left(\mathrm{SST},{ }^{\circ} \mathrm{C}\right), \mathrm{b}\right)$ sea surface Chl- $a$ concentration $\left(\mathrm{mg} \mathrm{Chl}-a \mathrm{~m}^{-3}\right)$, c) wind speed and direction $\left.\left(\mathrm{m} \mathrm{s}^{-1}\right), \mathrm{d}\right)$ daily tide range $(\mathrm{m})$ defined as the difference of highest and lowest daily sea level. Values above the long-term average indicate spring tides, and below the long-term average indicates neap tide periods. The average of each environmental variable is shown with a horizontal dotted line.

\section{Gelatinous zooplankton assemblage}

A total of 7,368 gelatinous zooplankton specimens were sorted out. From 22 observed gelatinous zooplankton taxa, only nine were identified to species level due to dehydration damage. The mean gelatinous zooplankton abundances are shown in Table 1. The analyzed gelatinous zooplankton was composed of siphonophores $(57 \%)$, thaliaceans $(42 \%)$, and hydromedusae (1\%) (Table 1). The gelatinous zooplankton assemblage showed seasonal changes in taxonomic composition and abundance during 2014. The three taxonomic groups decreased their abundance during the cold-warm transition (June) and increased their abundance during the hurricane season (SeptemberNovember) (Figs. 4a-c).

Siphonophores were collected throughout the year. The suborders Calycophorae and Cystonectae accounted for $99 \%$ and $1 \%$ of total siphonophore abundance, respectively. Only seven taxa were identified to species level due to morphological damage. Muggiaea atlantica Cunningham, 1892 was the most abundant species (25\%), followed by Diphyes dispar Chamisso \& Eysenhardt, 1821 (20\%), and Chelophyes contorta (Lens \& Van Riemsdijk, 1908) (19\%). The other four 
Table 1. Abundance of gelatinous zooplankton collected per week in Cabo Pulmo National Park (CPNP) during 2014. *Unidentified species.

\begin{tabular}{lccc}
\hline & $\begin{array}{c}\text { Average abundance } \\
\text { (ind } 1000 \mathrm{~m}^{-3} \text { ) }\end{array}$ & $\begin{array}{c}\text { Relative } \\
\text { abundance } \\
(\%)\end{array}$ & $\begin{array}{c}\text { Neritic-oceanic } \\
\text { habitat }\end{array}$ \\
\hline Thaliacea & 1208.80 & 96 & Oceanic \\
Thalia spp. & 48.40 & 4 & Oceanic \\
Doliolida* & & & \\
Hydrozoa & 15.24 & 73 & Neritic \\
Liriope tetraphylla & 3.02 & 15 & Neritic \\
Geryoniida** & 0.99 & 5 & - \\
Hydrozoa* & 0.59 & 3 & Neritic \\
Bougainvillia spp. & 0.27 & 1 & Oceanic \\
Aeginidae* & 0.26 & 1 & Neritic \\
Bougainvillia muscus & 0.26 & 1 & Neritic \\
Cytaeidida* & & & \\
Siphonophorae & 440.20 & 25 & Neritic \\
Muggiaea atlantica & 347.16 & 20 & Oceanic \\
Diphyes dispar & 326.04 & 19 & Neritic \\
Chelophyes contorta & 325.35 & 19 & - \\
Calycophorae* & 70.96 & 4 & Oceanic \\
Abylopsis spp. & 65.13 & 4 & Oceanic \\
Eudoxoides spp. & 43.60 & 3 & Oceanic \\
Diphyes bojani & 40.65 & 2 & Oceanic \\
Abylopsis eschscholtzii & 28.26 & 2 & Oceanic \\
Abylopsis tetragona & 20.90 & 1 & Oceanic \\
Diphyes spp. & 18.86 & 1 & Oceanic \\
Eudoxoides mitra & 4.12 & 0.2 & Neritic \\
Rhizophysa spp. & 0.91 & 0.05 & Neritic \\
Lensia spp. & & & \\
\hline &
\end{tabular}

species Abylopsis eschscholtzii (Huxley, 1859), A. tetragona (Otto, 1823), D. bojani (Eschscholtz, 1825), Eudoxoides mitra (Huxley, 1859), and Lensia spp. accounted combined for $8 \%$ of the total relative abundance of siphonophore. The rest of the siphonophores were identified into five other higher taxonomic levels accounting together for $27.8 \%$ of the total siphonophore abundance. Unidentified specimens of the genus Rhizophyza (Cystonectae) represented only $0.2 \%$ were the least abundant taxon of the total siphonophore (Table 1).

Taliaceans from the orders Salpida and Doliolida were collected in the 31 weeks of sampling. $96 \%$ of the total of thaliaceans were identified as Thalia spp. Unidentified specimens of the Order Doliolida accounted for the remaining 4\% (Table 1). Medusae only were collected during 19 sampling weeks. Liriope tetraphylla (Chamiso \& Eysenhardt, 1821) and Bougainvillia muscus (Allman, 1863) were the only observed hydromedusae species identified. Only three morphotypes belonging to the families Aeginidae, Geryoniidae, and Cytaeididae could be identified.
Liriope tetraphylla was the most abundant species of Medusae (73\%) (Table 1).

\section{Two-ways cluster analysis}

The two-ways cluster analysis showed two groups of zooplankton samples at a cut of $9 \%$ of similarity (Fig. $5)$. The first group $\left(\mathrm{G}_{1}\right)$ included mostly zooplankton samples collected during the cold (January-March, and November-December) and cold-warm transition (MayJune) periods. The second group $\left(\mathrm{G}_{2}\right)$ had mostly zooplankton samples collected during the warm (JulySeptember) and the cold-warm transition (April-May) periods. The $\mathrm{G}_{1}$ had zooplankton samples with higher abundance and species richness than samples from the $\mathrm{G}_{2}$. Each group was subdivided into two other subgroups at a cut of $26 \%$ similarity $\left(\mathrm{G}_{1 \mathrm{~A}-\mathrm{B}}\right.$ and $\mathrm{G}_{2 \mathrm{~A}-\mathrm{B}}$; Fig. 5). The subgroup $\mathrm{G}_{1 \mathrm{~A}}$ had samples from the cold season (January-March and November-December) and the subgroup $\mathrm{G}_{1 \mathrm{~B}}$ samples from the cold-warm transition period. The subgroup $\mathrm{G}_{2 \mathrm{~A}}$ included samples in the warmest month (Oct), and the subgroup $\mathrm{G}_{2 \mathrm{~B}}$ had samples from the rest of the warm season (July- 


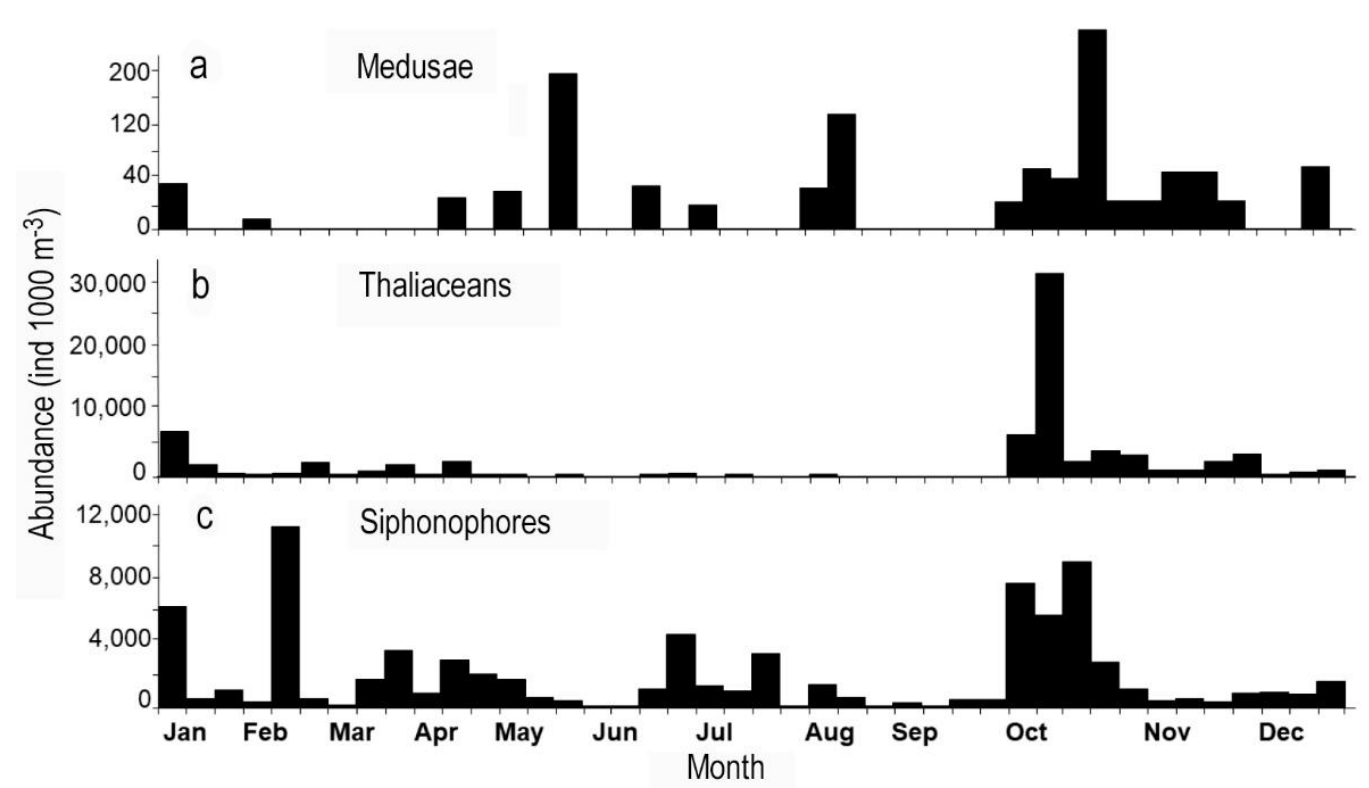

Figure 4. Standardized abundance (ind. $1000 \mathrm{~m}^{-3}$ ) of gelatinous zooplankton collected weekly in the Cabo Pulmo National Park during January-December 2014. a) Medusae, b) Thaliaceans, c) Siphonophores.

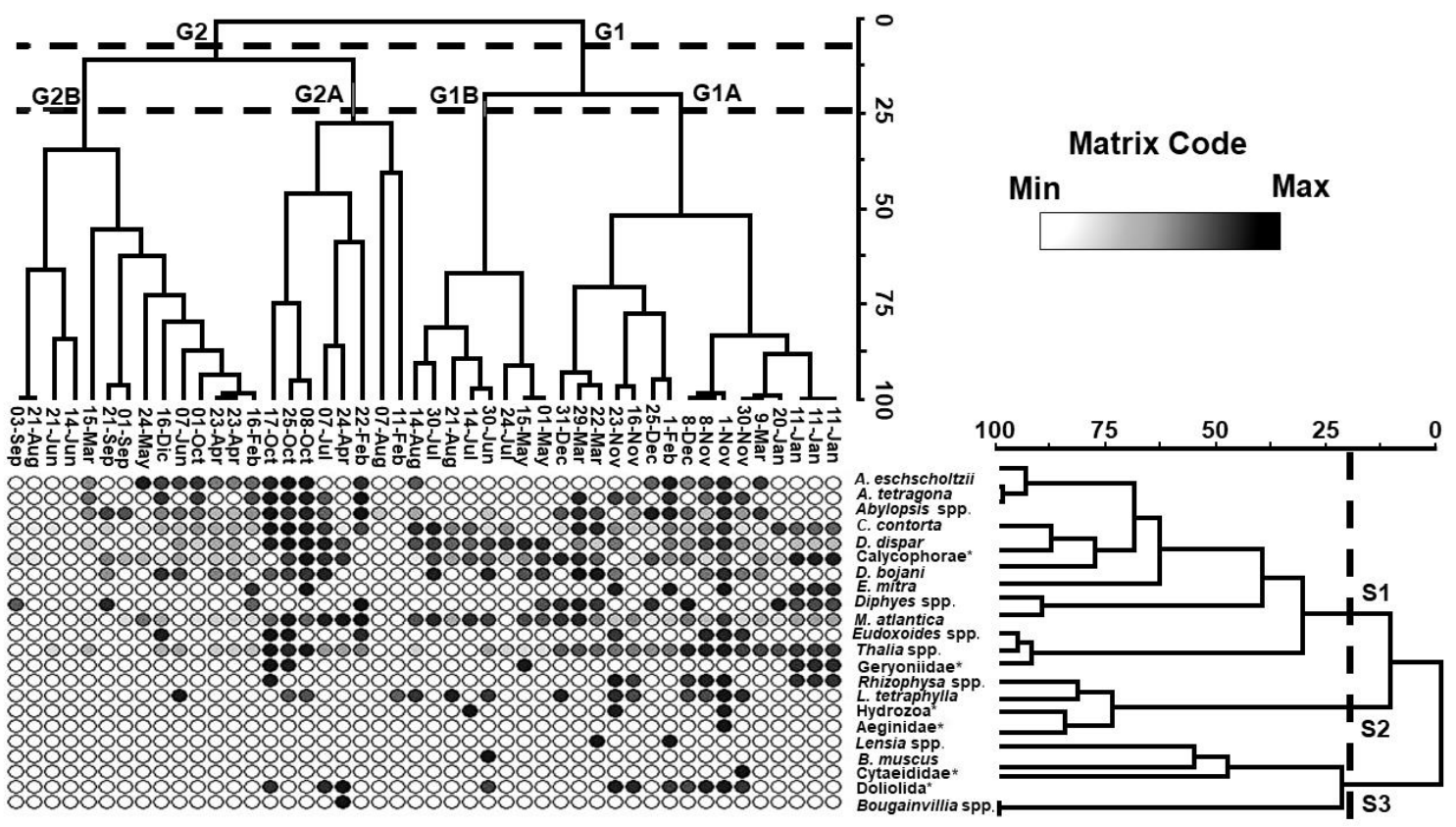

Figure 5. Two-ways cluster analysis of the gelatinous zooplankton collected during a weekly time series in the Cabo Pulmo National Park during January-December 2014. $\mathrm{G}_{1-2}$ : groups of weekly zooplankton sample units. $\mathrm{G}_{1 \mathrm{~A}-1 \mathrm{~B}-2 \mathrm{~A}-2 \mathrm{~B}}$ : subgroups of weekly zooplankton sample units. $S_{1-3}$ : Zooplankton taxonomic groups. Dashed lines indicate the cutoff point percentage of similarity among sampling units and zooplankton taxa. *Unidentified taxa.

September). Zooplankton community of gelatinous zooplankton showed significant differences among all four groups and subgroups of weekly sampling units (MRPP, $P<0.05$ ). Therefore, thaliaceans and medusae had significant seasonal changes during 2014, while siphonophores (mainly calycophorans) were present during the year. Siphonophores were less abundant but more diverse during the cold season than during the warm season at CPNP.

The two-ways cluster analysis showed three groups of the 22 gelatinous zooplankton taxa with a cut of $24 \%$ of similarity (Fig. 5). The first group $\left(S_{1}\right)$ included the 13 most frequent and abundant gelatinous zooplankton taxa of the CPNP (A. eschscholtzii, A. tetragona, 
Abylopsis spp., C. contorta, D. dispar), unidentified specimens from suborder Calycophorae, D. bojani, E. mitra, Diphyes spp., M. atlantica, Eudoxoides spp., Thalia spp., and unidentified specimens of the family Geryoniidae. The second group $\left(\mathrm{S}_{2}\right)$ had species with low abundance ( $L$. tetraphylla, unidentified specimens of family Aeginidae, Hydrozoa, and Rhizophysa spp.). The third group $\left(\mathrm{S}_{3}\right)$ included the less abundant and frequent species (Lensia spp., B. muscus, Bougainvillia spp. and unidentified specimens of the family Cytaeididae and order Doliolida). All three species groups showed significant seasonal differences in the mean abundance in CPNP (MRPP, $P<0.05$; Fig. 5).

\section{Non-metric multidimensional scaling}

The NMDS of the weekly zooplankton samples as a function of the five environmental variables showed a space-temporal relationship of gelatinous zooplankton and large zooplankton taxonomic group assemblages (Fig. 6a). Both axes explained $88.1 \%$ of the variability. Axis 1 explained $78.6 \%$ of the total variability with the highest positive association with SST and tidal height. Axis 2 explained $9.5 \%$ of total variability, mostly associated with SST and wind speed (Table 2). Zooplankton community had a negative relationship with the SST and a direct relationship with the Chl- $a$ and wind speed. Tropical species (D. dispar, A. tetragona, C. contorta, or Thalia spp.) increased abundance during the warm season. The most abundant species ( $M$. atlantica, L. tetraphylla, or $D$. dispar) was closely correlated with the most abundant zooplankton taxa (copepods, euphausiids, or decapods), showing possible interspecific trophic interactions due to overlap in time (Fig. 6a). The NMDS of the weekly zooplankton sample units showed warm conditions prevailed during 2014, and all the zooplankton assemblage was negatively associated with sea surface temperature and positively with the low concentrations of Chl- $a$ (Fig. 6b).

\section{DISCUSSION}

The present study demonstrated a tropical, and diverse gelatinous zooplankton taxonomic assemblage was present at CPNP associated with the anomalous warm environmental conditions that prevailed during 2014. Ahern et al. (2018) described a progressive increase of SST of the CPNP during 2000-2015 showing nine anomalous warm periods (positive SST anomalies) and a decline of Chl- $a$ concentration (negative anomalies). These anomalous warm conditions prevailed up to the end of 2019 at CPNP (Fig. 2). The last four warming events $(2009,2011,2014,2015,2016)$ were the warmest
Table 2. Non-metric multidimensional scaling (NMDS) results for sampling weeks and zooplankton taxa in Cabo Pulmo National Park (CPNP) during 2014, showing the coefficient of determination $\left(\mathrm{R}^{2}\right.$, axis $1=0.786$, Axis $2=$ $0.095)$ and Pearson \& Kendall correlation $(r)$ for the association between the gelatinous zooplankton community with the zooplankton community, based on the five environmental variables. *Unidentified species.

\begin{tabular}{|c|c|c|}
\hline Environmental variables & $\begin{array}{c}\text { Axe } 1 \\
r\end{array}$ & $\begin{array}{c}\text { Axe } 2 \\
r\end{array}$ \\
\hline Sea surface temperature $\left({ }^{\circ} \mathrm{C}\right)$ & 0.454 & 0.035 \\
\hline Sea surface chlorophyll- $a\left(\mathrm{mg} \mathrm{m}^{-3}\right)$ & -0.290 & -0.097 \\
\hline Wind velocity $\left(\mathrm{m} \mathrm{s}^{-1}\right)$ & -0.025 & 0.045 \\
\hline Wind direction $\left(^{\circ}\right)$ & -0.073 & -0.397 \\
\hline Tide range $(\mathrm{m})$ & 0.039 & -0.253 \\
\hline \multicolumn{3}{|l|}{ Gelatinous zooplankton } \\
\hline Abylopsis eschscholtzii & -0.206 & -0.554 \\
\hline Abylopsis tetragona & -0.243 & -0.647 \\
\hline Chelophyes contorta & -0.536 & -0.300 \\
\hline Diphyes bojani & -0.247 & -0.202 \\
\hline Diphyes dispar & -0.395 & -0.182 \\
\hline Eudoxoides mitra & -0.270 & -0.320 \\
\hline Abylopsis spp. & -0.155 & -0.691 \\
\hline Diphyes spp. & -0.135 & -0.132 \\
\hline Eudoxoides spp. & -0.203 & -0.505 \\
\hline Lensia spp. & -0.134 & -0.024 \\
\hline Muggiaea atlantica & -0.556 & -0.296 \\
\hline Calycophorae* & -0.436 & 0.072 \\
\hline Rhizophysa spp. & -0.290 & -0.333 \\
\hline Thalia spp. & -0.600 & -0.424 \\
\hline Doliolida* & -0.249 & -0.311 \\
\hline Bougainvillia muscus & -0.046 & 0.018 \\
\hline Hydrozoa* & -0.096 & -0.126 \\
\hline Aeginidae* & -0.102 & -0.257 \\
\hline Geryoniidae* & -0.231 & 0.042 \\
\hline Bougainvillia spp. & -0.074 & 0.181 \\
\hline Liriope tetraphylla & -0.233 & -0.315 \\
\hline Cytaeididae* & -0.025 & -0.155 \\
\hline
\end{tabular}

and progressively more prolonged periods with anomalous warm conditions recorded during the 20002015 period. During 2014 was recorded the highest winter temperatures $\left(22^{\circ} \mathrm{C}\right)$ even when compa-red with other previous warm years $\left(18^{\circ} \mathrm{C}\right.$ in 2008 and $20^{\circ} \mathrm{C}$ in 2011) relative to the 2000-2015 time series (Ahern et al., 2018) and 2003-2020 (Fig. 2). This unusual regional heatwave was simultaneous, but independent of the warm winter event of 2013-2014 in the North Pacific known as the "The Blob," generating an increase of the SST of $1-4^{\circ} \mathrm{C}$ above the average (Kintisch, 2015; Leising et al., 2015; Peterson et al., 2015, 2017; Beltrán-Castro et al., 2020). Boero et al. (2016) showed an increase in the medusae population size associated with warm conditions. The present study represents the first annual of time series of Sipho- 


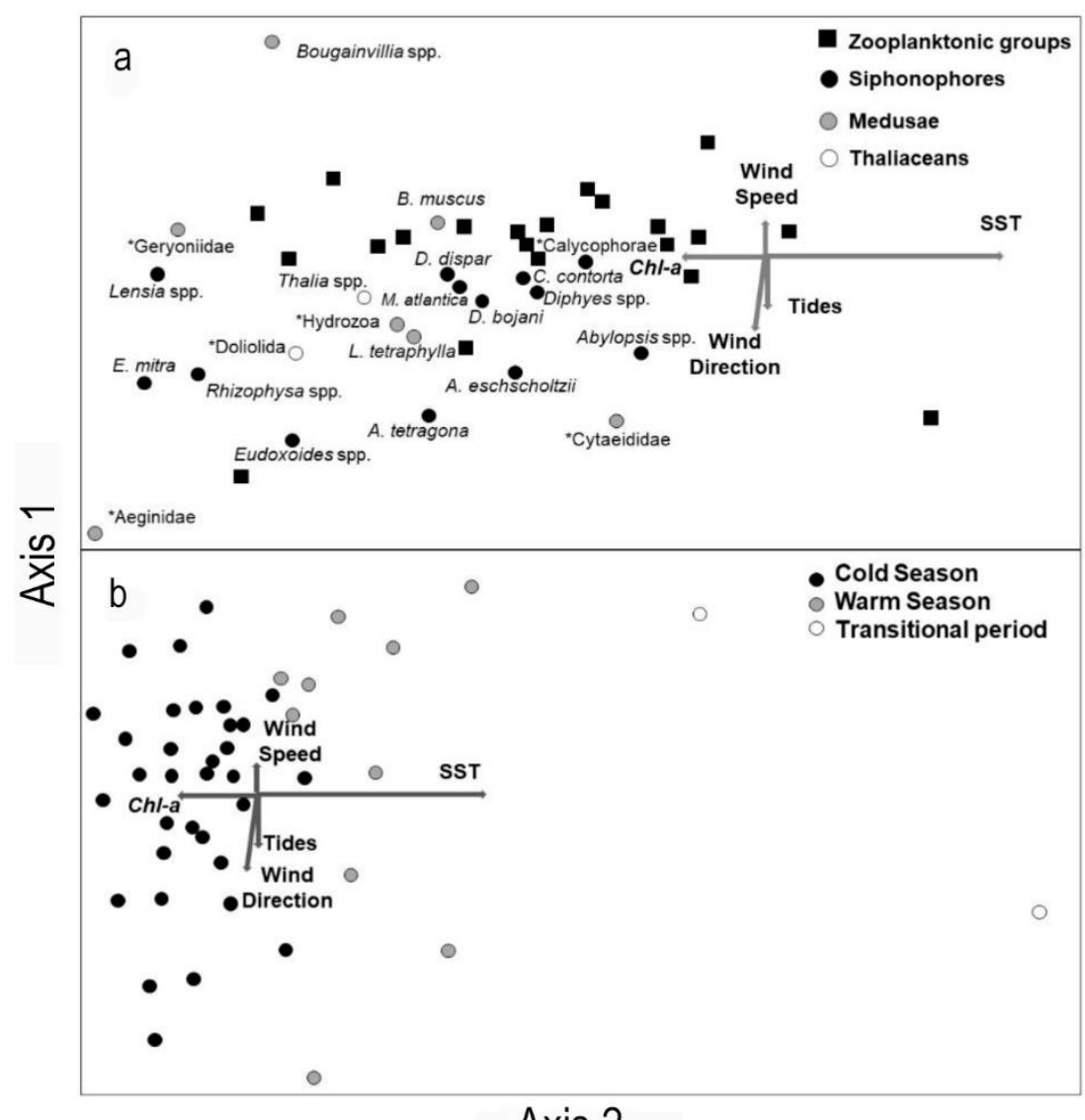

Axis 2

Figure 6. Non-metric multidimensional scaling (NMDS) of zooplankton community relationship identified with large taxonomic groups and gelatinous zooplankton taxa as a function of gradients of five environmental variables: a) gelatinous zooplankton and zooplankton taxonomic taxa; b) weekly sampling units ordered by seasonal climatic periods in the Cabo Pulmo National Park during 2014. *Unidentified species.

nophora, medusae, and thaliaceans in the Gulf of California, but is still unknown their long-term trends in abundance and species richness. However, all the species and taxa observed in CPNP were previously reported in the Gulf of California, even sampled and preserved with distinct methodologies during colder periods (Esquivel-Herrera, 1990), at offshore waters during 2014 (Guerrero-Ruiz, 2016) or along the west coast of Baja California Peninsula (Hereu et al., 2006). The absence of ctenophores, scyphozoans, or the low abundance of Lensia spp., Rhizophysa spp. or unidentified doliolids during 2014 was due to ethanol fixation and zooplankton deployment of the net that damaged or destroyed the colonies and individuals underestimating their abundance and diversity at CPNP. However, ctenophores were further collected during the 2015-2017 time series at CPNP (SilveyraBustamante, unpubl. data). Ethanol (70-95\%) is an adequate preserver for the identification of thaliaceans, doliolids, and other gelatinous species (Nishikawa \&
Terazaki, 1996; Sola et al., 2019) but not for ctenophores and large scyphozoans, which are more vulnerable to morphological disintegration and morphological damage when preserved with crustaceans that possess sharp spines (Thibault-Botha \& Bowen, 2004). Ethanol preservation favors DNA barcoding identification (not possible when preserved in formalin); therefore, it is expected that ethanol preservation becomes more frequently used in the future (Hosia et al., 2017; Bryant \& Arehart, 2019; Bucklin et al., 2019).

The tropical species $(C$. contorta, D. dispar, A. eschoscholtzii, M. atlantica, L. tetraphylla, B. muscus, and Thalia spp.) observed in CPNP during the anomalously warm year of 2014 have been previously reported associated to warm conditions in the Gulf of California and Mexican Pacific (Segura-Puertas, 1984; Gasca \& Suárez, 1991; Hereu et al., 2006). The anomalous warm conditions caused a lower Chl- $a$ concentration than those expected during colder 
previous years (Hidalgo-González \& Alvarez-Borrego, 2004; Espinosa-Carreón \& Valdez-Holguín, 2007). The mean sea surface Chl- $a$ concentration $(0.48 \mathrm{mg}$ $\mathrm{m}^{-3}$ ) observed during 2014 was about half lower the historical average observed between 1997-2016 (1 mg $\mathrm{m}^{-3}$ ) (Ahern et al., 2018; Beltrán-Castro et al., 2020), which could negatively influence the prey availability for carnivores and herbivores zooplankton decreasing their abundances (Alldredge, 1984). The relative abundance of siphono-phores and thaliaceans increased, concerning the other taxonomic groups, from $2 \%$ in 2005 to $10 \%$ in 2006 in response to anomalous cold and high sea surface Chl- $a$ concentration conditions in the Gulf of California (Jerónimo-Balcázar, 2011).

\section{Zooplankton community structure at CPNP}

Gelatinous zooplankton accounted for $<1 \%$ of the entire zooplankton community abundance at CPNP during 2014. They were suggesting a low influence of predation pressure upon their zooplanktonic and micronektonic prey, as observed in the central Gulf of California (Lavaniegos-Espejo \& Lara-Lara, 1990; Nava-Torres, 2003; Jerónimo-Balcázar, 2011) and other tropical regions of the world. Even though they were collected with different sampling methods or using genetic data (Boero et al., 2016; Casas et al., 2017; Sola et al., 2019), gelatinous zooplankton can occasionally be a large part of the biovolume of a zooplankton sample, even clogging or bursting the net (Palmieri et al., 2014). The diversity of gelatinous species observed at CPNP was lower than the observed in the oceanic species assemblage reported in the southern Gulf of California during summer 2014, except A. tetragona only observed at CPNP (GuerreroRuiz, 2016). The "oceanic" gelatinous species assemblage collected at CPNP was promoted by this narrow and shallow ( $<25 \mathrm{~m}$ depth) continental shelf at CPNP influenced by a south deep canyon and onshore oceanic currents that facilitates the dynamic interaction between coastal-oceanic fauna (Fig. 1a, Table 1) (Trasviña-Castro et al., 2012; Ahern et al., 2018) as having been observed in other regions of the world (Nogueira et al., 2018).

Zooplankton at CPNP collected using a conical net towed horizontally at the surface had lower diversity than all other previous studies in the Gulf of California that used oblique tows with Bongo nets from $300 \mathrm{~m}$ depth to surface (Esquivel-Herrera, 1990; Alvariño, 1991; Suárez \& Gasca, 1991; Guerrero-Ruiz, 2016). Several species that have deep daytime vertical distribution, like L. tetraphylla or Rhizophysa spp. (Alvariño, 1971). Zooplankton is mostly concentrated near the surface where they feed at night as part of their daily vertical migration, maximizing feeding and minimizing the chances of being predated (hungersatiation hypothesis) (Nogueira et al., 2015). The thermocline can influence the vertical distribution of zooplankton (Pagès \& Gili, 1991). However, the CPNP sampling site was about $25 \mathrm{~m}$ depth, so we expected that near-surface $(<5 \mathrm{~m})$ zooplankton has resemblance with zooplankton from deeper strata in such location.

\section{Gelatinous zooplankton and zooplankton commu- nity at CPNP}

We initially expected that during periods of high abundance and diversity of carnivorous siphonophores or medusae may cause a predation pressure that would modify species composition and abundance of the other taxonomic groups. However, the relative abundance of gelatinous zooplankton at CPNP during 2014 was relatively low $(<1 \%$ of total zooplankton community structure), and likely did not play a significant control over the abundance of other zooplankton taxonomic groups during 2014 . The low diversity and abundance of siphonophores, medusae, and thaliaceans were associated with low zooplankton biovolume and Chl- $a$ concentration under oligotrophic conditions (Suárez \& Gasca, 1991) and mesotrophic conditions at CPNP during 2014 (Ahern et al., 2018).

The NMDS showed that the most abundant species (M. atlantica, D. dispar, C. contorta, L. tetraphylla, and Thalia spp.) had a positive correlation with the abundance of copepods, cladocerans, euphausiids, and fish larvae (potential preys). Although the NMDS and the two-ways cluster analysis were not useful to infer trophic interactions, spatial-temporal coincidence at the sampling station at CPNP suggested possible depredator-prey trophic associations among carnivorous gelatinous and other groups. M. atlantica is a predator of sardine eggs and larvae (Purcell, 1982; Funes-Rodríguez, 1985). D. dispar is a predator of anchovy larvae (Alvariño, 1980), and L. tetraphylla consumes large numbers of zooplanktonic crustaceans (Yilmaz, 2014). When the abundance of L. tetraphylla was higher than $70 \%$ of the total zooplankton abundance shown a significant predation influence over anchovy larvae in the California Current (Alvariño, 1980) and shallow coastal waters from Brazil (Nagata et al., 2014); which was a similar proportion of medusae abundance observed at that CPNP. CPNP is a tropical habitat for gelatinous zooplankton, and their presence should be analyzed in the future using more appropriated methodologies for molecular and morphological taxonomic analysis to evaluate the potential ecological impact of gelatinous species on the rest of the zooplankton assemblages that sustain the diverse neritic trophic web at Cabo Pulmo National Park. 


\section{ACKNOWLEDGMENTS}

We sincerely thank the David I. Castro Arvizú and Castro family for their unconditional and invaluable help in collecting weekly zooplankton samples at Cabo Pulmo National Park (January 2014-November 2017). We thank the Comisión Nacional de Áreas Naturales Protegidas (CONANP), particularly Carlos Ramón Godínez-Reyes, for the permissions given for the current research project, and members of the Gulf of California Marine Program for their help with logistic issues of the current project, especially Octavio AburtoOropeza (SIO-UCSD), Juan José Cota-Nieto, Arturo Ramírez-Valdez, and José Alfredo Giron-Nava. J.G.-G. received support from the Centro Interdisciplinario de Ciencias Marinas, Instituto Politécnico Nacional (CICIMAR-IPN, Coordinación General de Posgrado e Investigación grants in 2014-2017), and a Secretaría de Educación Pública-Consejo Nacional de Ciencia y Tecnología (SEP-CONACYT) grants CB-2012178615-01 and CB-2016-01-284201. J.G.-G. is a fellow of the Comisión de Operación y Fomento de Actividades Académicas (COFAA-IPN) and Programa de Estímulos al Desempeño de los Investigadores (EDIIPN) at the IPN, and the Sistema Nacional de Investigadores. Additional funding was provided by the Walton Family Foundation, Helmsley Charitable Trust, International Community Foundation, and David and Lucile Packard Foundation.

\section{REFERENCES}

Aburto-Oropeza, O., Erisman, B., Galland, G., Mascareñas-Osorio I., Sala, E. \& Ezcurra, E. 2011. Large recovery of fish biomass in a no-take marine reserve. Plos One, 6(8): e23601.

Aburto-Oropeza, O., Ezcurra, E., Moxley, J., SánchezRodríguez, A., Mascareñas-Osorio, I., Sánchez-Ortiz, C., Erisman, B. \& Ricketts, T. 2015. A framework to assess the health of rocky reefs linking geomorphology, community assemblage, and fish biomass. Ecological Indicators, 52: 353-361.

Ahern, A., Gómez-Gutiérrez, J., Aburto-Oropeza, O., Saldierna-Martínez, R., Johnson, A., Harada, A., et al. 2018. DNA sequencing of fish eggs and larvae reveals high species diversity and seasonal changes in spawning activity in the southeastern Gulf of California. Marine Ecological Progress Series, 592: 158-179.

Alldredge, A. 1984. The quantitative significance of gelatinous zooplankton as pelagic consumers. In: Fasham, M.J.R. (Ed.). Flows of energy and materials in marine ecosystems. Plenum Press, New York, pp. 407-433.
Alldredge, A. \& Madin, L. 1982. Pelagic tunicates: unique herbivores in the marine plankton. BioScience, 32(8): 665-663.

Alvariño, A. 1971. Siphonophores of the Pacific with a review of the world distribution. Bulletin Scripps Institution Oceanography, 16: 1-432.

Alvariño, A. 1980. The relation between the distribution of zooplankton predators and anchovy larvae. California Cooperative Oceanic Fisheries Investigation Report, 21: 150-161.

Alvariño, A. 1991. Abundancia y distribución batimétrica diurna y nocturna de los sifonóforos durante cuatro estaciones del año 1969, en aguas de California y Baja California. Investigaciones Marinas CICIMAR, 6(2): 1-37.

Attrill, M., Wright, J. \& Edwards, M. 2007. Climaterelated increases in jellyfish frequency suggest a more gelatinous future for the North Sea. Limnology and Oceanography, 52(1): 480-485.

Badan, A. 2003. The effects of El Niño in Mexico: a survey. Geofísica Internacional, 42(3): 567-571.

Bailey, T., Youngbluth, M. \& Owen, G. 1995. Chemical composition and metabolic rates of gelatinous zooplankton from midwater and benthic boundary layer environments off Cape Hatteras, North Carolina, USA. Marine Ecology Progress Series, 122: 121-134.

Boero, F., Brotz, L., Gibbons, M., Piraino, S. \& Zampardi, S. 2016. Impacts and effect of ocean warming on jellyfish. In: Laffoley, D. \& Baxter, J. (Eds.). Explaining ocean warming: causes, scale, effects and consequences. IUCN, Gland, pp. 213-327.

Beltrán-Castro, J.R., Hernández-Trujillo, S., GómezGutiérrez, J., Trasviña-Castro, A., González-Rodríguez, E. \& Aburto-Oropeza, O. 2020. Copepod species assemblage and carbon biomass during two anomalous warm periods of distinct origin (2014-2015) in the southern Gulf of California. Continental Shelf Research. 207: 104-215.

Bouillon, J. 1999. Hydromedusae. In: Boltovskoy, D. (Ed.). South Atlantic zooplankton. Backhuys Publishers, Leiden, pp. 385-561.

Brinton, E., Fleminger, A. \& Siegel-Causey, D. 1986. The temperate and tropical planktonic biota of the Gulf of California. California Cooperative Oceanic Fisheries Investigation Report, 27: 228-266.

Brodeur, R., Mills, C., Overland, J., Walters, G. \& Schumacher, J. 1999. Evidence for substantial increase in gelatinous zooplankton in the Bering Sea, with possible links to climate change. Fisheries Oceanography, 8(4): 296-306.

Bryant, P. \& Arehart, T. 2019. Diversity and life-cycle analysis of Pacific Ocean zooplankton by videomi- 
croscopy and DNA barcoding: Hydrozoa. Plos One, 14(10): $\mathrm{e} 0218848$.

Bucklin, A., Yeh, H., Questel, J., Richardson, D., Reese, B., Copley, N. \& Wiebe, P. 2019. Time-series metabarcoding analysis of zooplankton diversity of the NW Atlantic continental shelf. ICES Journal of Marine Science, 76(4): 1162-1176.

Casas, L., Pearman, J. \& Irigoien, X. 2017. Metabarcoding reveals seasonal and temperature-dependent succession of zooplankton communities in the Red Sea. Frontiers in Marine Science, 4: 241.

Cavole, L., Demko, A., Diner, R., Giddings, A., Koester, I., Pagniello, C., et al. 2016. Biological impacts of the 2013-2015 warm-water anomaly in the Northeast Pacific: winners, losers, and the future. Oceanography, 29(2): 273-285.

Chin, T., Vázquez, J. \& E. Armstrong. 2017. A multiscale, high-resolution analysis of global sea surface temperature. Remote Sensing of Environment, 200: 154-169.

Condon, R., Graham, W., Duarte, C., Pitt, K., Lucas, C., Haddock, H., et al. 2012. Questioning the rise of gelatinous zooplankton in the world's oceans. BioScience, 62(2): 160-169.

Diaz-Briz, L., Sánchez, F., Marí, N. \& Genzano, G. 2018. Seasonal variation of gelatinous plankton consumption by fish in the South-western Atlantic Ocean: a question of strategy. Marine Biology Research, 14(7): 739-751.

Diaz-Briz, L., Sánchez, F., Marí, N., Mianzan, H.W. \& Genzano, G. 2017. Gelatinous zooplankton (ctenophores, salps and medusae): an important food resource of fishes in the temperate SW Atlantic Ocean. Marine Biology Research, 13(6): 630-644.

Espinosa-Carreón, L. \& Valdez-Holguín, E. 2007. Gulf of California interannual chlorophyll variability. Ecología Aplicada, 6(1-2): 83-92.

Esquivel-Herrera, A. 1990. Caracterización de las comunidades de sifonóforos del Golfo de California 1984-1986. Tesis de Magíster, IPN-CICIMAR, La Paz, 192 pp.

Finenko, G., Romanova, A., Abolmasova, G., Anninsky, B., Pavlovskaya, T., Bat, L. \& Kideys, A. 2006. Ctenophores-invaders and their role in the trophic dynamics of the planktonic community in the coastal regions off the Crimean coasts of the Black Sea (Sevastopol Bay). Oceanology, 46(4): 472-482.

Funes-Rodríguez, R. 1985. Abundancia de sifonóforos y larvas de Sardinops sagax caerulea en el invierno (1981-1982) en Bahía Magdalena B.C.S. México. Investigaciones Marinas CICIMAR, 2(2): 70-76.

Gasca, R. \& Haddock, S. 2004. Associations between gelatinous zooplankton and hyperiid amphipods
(Crustacea: Peracarida) in the Gulf of California. Hydrobiologia, 530(1-3): 529-535.

Gasca, R. \& Suárez, E. 1991. Siphonophores of upwelling areas of the Campeche Bank and the Mexican Caribbean Sea. Hydrobiologia, 216: 497-502.

Ghermandi, A., Galil, B., Gowdy, J. \& Nunes, P. 2015. Jellyfish outbreak impacts on recreation in the Mediterranean Sea: welfare estimates from a socioeconomic pilot survey in Israel. Ecosystem Services, 11: 140-147.

Godeaux, J.E. 2003. History and revised classification of the order Cyclomayaria (Tunicata, Thaliacea, Doliolida). Bulletin de 1'Institut Royal des Sciences Naturelles de Belgique, Biologie, 73: 191-222.

Gómez-Gutiérrez, J., Peterson, W.T. \& Miller, C. 2005. Cross-shelf life-stage segregation and community structure of the euphausiids off central Oregon (19701972). Deep-Sea Research Part II: Topical Studies in Oceanography, 52(1-2): 289-315.

Graham, W., Gelcich, S., Robinson, K., Duarte, C., Brotz, L., Purcell, J., et al. 2014. Linking human well-being and jellyfish: ecosystem services, impacts, and societal responses. Frontiers in Ecology and the Environment, 12(9): 515-523.

Guerrero-Ruiz, J. 2016. Estructura de la comunidad de medusas y sifonóforos (Phylum: Cnidaria) del Golfo de California en el verano de 2014. Tesis de Magíster, IPN-CICIMAR, La Paz, 92 pp.

Hamner, W.M., Madin, L., Alldredge, A., Gilmer, R. \& Hamner, P. 1975. Underwater observations of gelatinous zooplankton: sampling problems, feeding biology, and behavior. Limnology and Oceanography, 20(6): 907-917.

Hereu, C., Lavaniegos, B., Gaxiola-Castro, G. \& Ohman, M. 2006. Composition and potential grazing impact of salp assemblages off Baja California during the 19971999 El Niño and La Niña. Marine Ecology Progress Series, 318: 123-140.

Hidalgo-González, R.M. \& Alvarez-Borrego, S. 2004. Total and new production in the Gulf of California estimated from ocean color data from the satellite sensor SeaWiFS. Deep-Sea Research Part II: Topical Studies in Oceanography, (51): 739-752.

Hosia, A., Falkenhaug, T., Baxter, E. \& Pagès, F. 2017. Abundance, distribution and diversity of gelatinous predators along the northern Mid-Atlantic Ridge: a comparison of different sampling methodologies. Plos One, 12(11): e0187491.

Jerónimo-Balcázar, J. 2011. Variación interanual de las larvas de peces pelágicos menores en el Golfo de California y su relación con el zooplancton y el ambiente durante marzo de 2005 y 2006. Tesis de Magíster, IPN-CICIMAR, La Paz, 80 pp. 
Kim, S.W., Lee, J. \& Kim, C. 2010. Taxonomic study of family Doliolidae (Urochordata: Thaliacea: Doliolida) from Korea. Korean Journal of Systematic Zoology, 26(1): 11-14.

Kim, S.W., Won, J. \& Kim, C. 2011. Taxonomic study of the genus Thalia (Thaliacea: Salpida: Salpidae) from Korea. Animal Systematics, Evolution and Diversity, 27(2): 142-150.

Kintisch, E. 2015. 'The Blob' invades Pacific flummoxing climate experts. Science, 348(6230): 17-18.

Lavaniegos-Espejo, B.E. \& Lara-Lara, J. 1990. Zooplankton of the Gulf of California after the 19821983 El Niño event: biomass distribution and abundance. Pacific Science, 44(3): 297-310.

Leising, A.W., Schroeder, I., Bograd, S., Abell, J., Durazo, R., Gaxiola-Castro, G., et al. 2015. State of the California Current 2014-15: impacts of the warmwater "Blob." California Cooperative Oceanic Fisheries Investigation Report, 56: 31-68.

Mapstone, G. \& Arai, M. 2009. Siphonophora (Cnidaria: Hydrozoa) of Canadian Pacific waters. NRC Research Press, Calgary.

Martinussen, M. \& Båmstedt, U. 1999. Nutritional ecology of gelatinous planktonic predator. Digestion rate in relation to type and amount of prey. Journal of Experiment Marine Biology and Ecology, 232(1): 6184.

McCune, B., Grace, J. \& Urban, D. 2002. Analysis of ecological communities. MjM Software Desing, Oregon.

Nagata, R., Nogueira, M., Brandini, F. \& Haddad, M. 2014. Spatial and temporal variation of planktonic cnidarian density in subtropical waters of the southern Brazilian Bight. Journal of the Marine Biological Association of the United Kingdom, 94(7): 13871400.

Nava-Torres, A. 2003. Distribución y abundancia del zooplancton en el Golfo de California, México de Febrero 1988. Tesis de Licenciatura, Universidad Autónoma de Baja California del Sur, La Paz, 203 pp.

Nishikawa, J. \& Terazaki, M. 1996. Tissue shrinkage of two gelatinous zooplankton, Thalia democratica and Dolioletta gegenbauri (Tunicata: Thaliacea) in preservative. Bulletin of Plankton Society of Japan, 43(1): 1-7.

Nogueira, M., Pereira, F. \& Ugaz, J. 2015. Diel vertical dynamics of gelatinous zooplankton (Cnidaria, Ctenophora and Thaliacea) in a subtropical stratified ecosystem (south Brazilian Bight). Plos One, 10(12): e0144161.

Nogueira, M., Da Costa, B., Martínez, T., Brandini, F. \& Miyashita, L. 2018. Diversity of gelatinous zoo- plankton (Cnidaria, Ctenophora, Chaetognatha and Tunicata) from a subtropical estuarine system, southeast Brazil. Marine Biodiversity, 49(3): 1-16.

Pagès, F. \& Gili, J. 1991. Vertical distribution of epipelagic siphonophore at the confluence between Benguela waters and the Angola Current over 48 hours. Hydrobiologia, 216(217): 355-362.

Palma, S. 1973. Contribución al estudio de los sifonóforos encontrados frente a la costa de Valparaíso. I. Taxonomía. Investigaciones Marinas, Valparaíso, 4(2): 1788.

Palmieri, M., Barausse, A., Luisetti, T. \& Turner, K. 2014. Jellyfish blooms in the northern Adriatic Sea: fishermen's perceptions and economic impacts on fisheries. Fisheries Research, 155: 51-58.

Peterson, W.T., Robert, M. \& Bond, N. 2015. The warm Blob continues to dominate the ecosystems of the northern California Current. PISCES Press, 23(2): 4446.

Peterson, W.T., Fisher, J., Strub, P., Du, X., Risien, C., Peterson, J. \& Shaw, C. 2017. The pelagic ecosystem in the Northern California Current off Oregon during the 2014-2016 warm anomalies within the context of the past 20 years. Journal of Geophysical Research: Oceans, 122(9): 7267-7290.

Pugh, P. 1999. Siphonophorae. In: Boltovskoy, D. (Ed.). South Atlantic zooplankton. Backhuys Publishers, Leiden, pp. 467-511.

Purcell, J.E. 1980. Influence of siphonophore behavior upon their natural diets: evidence for aggressive mimicry. Science, 209(4460): 1045-1047.

Purcell, J.E. 1982. Feeding and growth of the siphonophore Muggiaea atlantica (Cunningham, 1893). Journal of Experimental Marine Biology and Ecology, 62(11): 39-54.

Purcell, J.E. 2005. Climate effects on formation of jellyfish and ctenophore blooms a review. Journal of the Marine Biological Association of the United Kingdom, 85(3): 461-476.

Purcell, J.E. 2008. Extension for methods for jellyfish and ctenophore trophic ecology to large-scale research. Hydrobiologia, 616: 23-50.

Robinson, C. 2016. Evolution of the 2014-2015 sea surface temperature warming in the central west coast of Baja California, Mexico, recorded by remote sensing. Geophysical Research Letters, 43(13): 70667071.

Robinson, C.J., Gómez-Gutiérrez, J. \& Salas, D. 2013. Jumbo squid (Dosidicus gigas) landings in the Gulf of California related to remotely sensed SST and concentrations of chlorophyll-a (1998-2012). Fisheries Research, 137: 97-103. 
Robinson, C.J., Gómez-Gutiérrez, J., Markaida, U. \& Gilly, W. 2016. Prolonged decline of jumbo squid (Dosidicus gigas) landings in the Gulf of California is associated with chronically low wind stress and decreased chlorophyll- $a$ after El Niño 2009-2010. Fisheries Research, 173: 128-138.

Russell, F. 1953. The medusae of the British Isles. University Printing House, Cambridge.

Segura-Puertas, L. 1984. Morphology, systematics and zoogeography of medusae (Cnidaria: Hydrozoa and Scyphozoa from the eastern Tropical Pacific. Instituto de Ciencias del Mar y Limnología, Universidad Autónoma de México, 8: 1-315.

Smith, P. \& Richardson, S. 1979. Técnicas modelo para prospección de huevos y larvas de peces pelágicos. FAO, Documentos Técnicos de Pesca FIR/T175 (Es), 175: 107-108.

Sola, J., Klein, S., Martin, C., Agustí, S. \& Duarte, C. 2019. Gelatinous zooplankton in the surface layer of the coastal central Red Sea. Frontiers in Marine Science, 6: 726 .

Received: 8 October 2019; Accepted: 7 July 2020
Suárez, E. \& Gasca, R. 1991. Sifonóforos de México, biología y ecología. Editorial CIQRO, Quintana Roo.

Thibault-Botha, D. \& Bowen, T. 2004. Impact of formalin preservation on Pleurobranchia bachei (Ctenophora). Journal of Experimental Marine Biology and Ecology, 303(1): 11-17.

Trasviña-Castro, A.T., Aburto-Oropeza, O., Ezcurra, E. \& Zaytsev, O. 2012. Observaciones de corrientes en el Parque Nacional de Cabo Pulmo, Baja California Sur: mediciones eulerianas en verano, otoño e inicios del invierno. Geos, 32: 323-341.

Yilmaz, N.I. 2014. Collapse of zooplankton stock during Liriope tetraphylla (Hydromedusa) blooms and dense mucilaginous aggregations in a thermohaline stratified basin. Marine Ecology, 36(3): 595-610.

Yount, J. 1954. The taxonomy of the Salpide (Tunicata) of the Central Pacific Ocean. Pacific Science, 8: 276330. 